JRNAL ПMПAH

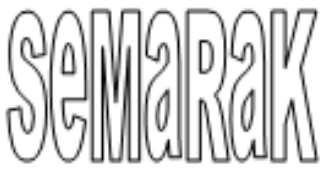

P-ISSN 2615-6849, E-ISSN 2622-3686

Jurnal Semarak,Vol.4,No.2,Juni 2021, Hal (81-89)

@Prodi Manajemen Fakultas Ekonomi Universitas Pamulang

\title{
PENGARUH RETURN ON ASSET, EARNING PER SHARE, DAN PRICE EARNING RATIO TERHADAP HARGA SAHAM (Studi kasus PT ASTRA INTERNASIONAL Tbk)
}

\author{
Jeni Irnawati \\ Fakultas Ekonomi Universitas Pamulang \\ dosen02228@unpam.ac.id
}

\begin{abstract}
ABSTRAK
Tujuan penelitian untuk menguji pengaruh antara ROA, EPS, dan PER terhadap harga saham. Metode penelitian menggunakan kuantittaif, menggunakan data time series, dengan software Eviews 10. Hasilnya menunjukan bahwa ROA tidak berpengaruh signifiikan terhadap harga saham, karena dari hasil $\mathrm{t}_{\text {hitung }} 1,205867<\mathrm{t}_{\text {tabel }} 2,44691$ dan nilai probabilitasnya $>0,05$ yaitu 0,2733. Sementara variabel EPS dan PER terhadap saham masing-masing menunjukkan hasil berpengaruh signifikan terhadap harga saham, dengan nilai probabilitas nya < dari taraf sginifikan sebesar 0,0003 dan 0,0012. Kemudian secara simultaneous ROA, EPS, dan PER memiiki pengaruh signifikan terhadap harga saham dimana hasil menunjukkan bahwaF $F_{\text {hitung }}$ $68,41732>\mathrm{F}_{\text {tabel }} 4,76$ dengan nilai probabilitasnya $0,000050<0,05$. Hal tersebut diperkuat oleh nilai presentase dari Adjusted $R$-Squared adalah sebesar $95,73 \%$, bahwa semua variable independen ROA, EPS, dan PER sifat korelasi nya sangat kuat terhadap harga saham.
\end{abstract}

Kata Kunci:ROA, EPS, PER, dan Harga Saham

\section{ABSTRACT}

The research objective was to examine the effect of ROA, EPS, and PER on stock prices at PT Astra International, Tbk in 2009-2018. The research method uses quantitative, using time series data, with Eviews 10 software. The results show that ROA does not have a significant effect on stock prices, because the results of tcount 1.205867 <ttable 2.44691 and the probability value> 0.05, namely 0.2733. Meanwhile, the EPS and PER variables for each share showed a significant effect on stock prices, with the probability value <from significant levels of 0.0003 and 0.0012. Then simultaneously ROA, EPS, and PER have a significant effect on stock prices where the results show that Fcount 68.41732> Ftable 4.76 with a probability value of 0.000050 $<0.05$. This is reinforced by the percentage value of the Adjusted R-Squared, which is $95.73 \%$, that all independent variables ROA, EPS, and PER have a very strong correlation with stock prices.

\section{Keywords: Return On Assets, Earning Per Share, Price Earning Ratio, dan Stock Price}

\section{PENDAHULUAN}

\section{A. Latar Belakang}

Industri alami perkembangan dari tahun ke tahun, khususnya di Indonesia telah mengalami kenaikan dan penurunan secara dinamis. Khususnya perusahaan yang berada di sub sektor otomotif dan komponen. Secara umum sektor otomotif dan komponen dapat dibedakan menjadi 2 bagian yaitu sektor produsen kendaraan dan produksi sparepart kendaraan. Sektor produsen kendaraan adalah untuk menjual 
JRNAL ПММАH

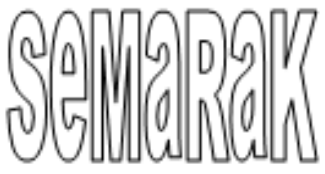

Jurnal Semarak,Vol.4,No.2,Juni 2021, Hal (81-89)

@Prodi Manajemen Fakultas Ekonomi Universitas Pamulang

hasil produksi nya seperti mobil-mobil ataupun kendaraan bermotor lainnya,sementara produksi sparepart kendaraan yang digunakan untuk membuat kendaraan bermotor tersebut. Semua sektor tersebut dimiliki oleh PT Astra Internasional Tbk. Perusahaan ini tentu memiliki produk-porduk yang hampir menguasai Market Share di indonesia. Mengutip dari artikel. "Berdasarkan data yang dirilis PT. Astra Internasional Tbk, mereka masih mendominasi volume penjualan otomitif nasional dengan menguasai market share 51 persen. Meskipun terjadi penurunan dari tahun 2017 yang sebelumnya tercatat 54 persen. Dari empat merek dalam lingkup PT. Astra Internasional, tiga merek menunjukkan pertumbuhan positif yaitu Astra Daihatsu Motor, Isuzu Astra Motor Indonesia (IAMI), dan Peugeot Sales Operations".

$$
\text { Mengenai sektor otomotif }
$$

,masuknya mobil listrik ke Indonesia, pemertintah mulai memberikan insentif kepada masyarakat yang menggunakan mobil tersebut. Salah satu anak perusahaannya sudah mulai mempersiapkan untuk memporduksi spare parts dari pada mobil listrik tersebut. Berdasarkan hal tersebut diatas, maka perusahaan membutuhkan modal yang cukup untuk mendanai berbagai kegiataan perusahaan agar perusahaan tersebut bisa mendapatkan keuntungan secara maksimal, karena bisnis dari PT. Astra Internasional, Tbk mayoritas bersumber dari sektor otomotif.

Berkaitan dengan penjelasan di atas, alasan perusahaan harus memiliki tujuan yang jelas agar perusahaan dapat memiliki keuntungan yang maksimal. Tujuan perusahaan yang ketiga yaitu memaksimalkan nilai perusahaan yang terlihat pada harga sahamnya. Dan secara berkaitan, untuk mencapai suatu tujuan perusahaan harus mempunyai modal yang cukup untuk operasional sehingga perusahaan memenuhi kebutuhan dana atau modal dari saham atau obligasi.
Undang-Undang No. 8 (1995) tentang pasar modal, mendefinisikan "pasar modal sebagian kegiatan yang bersangkutan dengan penawaran umum dan perdagangan efek yang di terbitkan, serta lembaga dan profesi yang berkaitan dengan efek". Jadi dapat dikatakan bahwa sarana atau fasilitas untuk pemodal adalah pasar modal. Umumnya investor menginvestasikan sahamnya untuk memperoleh capital gain.. Oleh karena nya seorang investor harus bisa memastikan harga saham mana yang baik, karena harga saham adalah penggambaran atas nilai suatu perusahaan yang di pengaruhi oleh prestasi, kinerja perusahaan. Apabila harga saham selalu mengalami kenaiakan, maka investor akan menilai bahwa perusahaan tersebut berhasil dan begtu pula sebaliknya, apabila harga saham mengalami penurunan berarti nilai suatu perusahaan di mata invesor tidak terlalu baik.

Oleh karena itu para investor yang menginginkan hasil (return) pasti akan memperhatikan aspek fundamental. Salah satu faktor fundamental yang dapat dilihat adalah kondisi dari dalam perusahaan (internal). Karena di dalam kondisi internal perusahaan menggambarkan kinerja dari suatu perusahaan itu sendiri. Kinerja suatu perusahaan dapat diukur menggunakan laporan keuangan perusahaan yang tercermin dari beberapa rasio-rasio keuangan. Dengan adanya hal tersebut maka perusahaan dapat mengambil suatu keputusan yang baik dan tentunya yang dapat menguntungkan bagi perusahaan. Apabila perusahaan dapat mengeola modal usahanya dengan efektif dan efisien, maka dapat memberikan suatu kepuasan kepada investor, karena tingkat hasil (return) yang mereka dapatkan sesuai dengan ekspektasi dengan beberapa faktor yang sudah di perhitungkan.

Berdasarkan penjelasan latar belakang, peneliti akan membahas tentang "PENGARUH RETURN ON ASSET (ROA), EARNING PER SHARE (EPS), dan PRICE EARNING RATIO TERHADAP HARGA SAHAM PADA 
JRNAL ПММАH

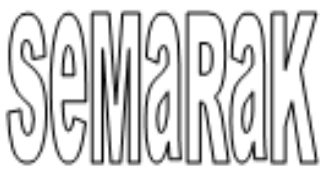

Jurnal Semarak,Vol.4,No.2,Juni 2021, Hal (81-89)

@Prodi Manajemen Fakultas Ekonomi Universitas Pamulang

PT. ASTRA INTERNASIONAL Tbk. TAHUN 2009-2018".

\section{B. Rumusan Masalah.}

Merangkum pembahasan sebelumnya, penulis mencatat perumusan masalah dibawah ini:

1. Bagaimana pengaruh $R O A$ secara parsial terhadap harga saham di PT Astra Internasional Tbk. periode 2009-2018?

2. Bagaimana pengaruh EPS secara parsial terhadap harga saham di PT Astra Internasional Tbk periode 20092018?

3. Bagaimana pengaruh PER secara parsial terhadap harga saham di PT Astra Internasional, Tbk periode 20092018?

4. Bagaimana pengarruh ROA, EPS, dan PER secara simultaneous terhadap harga saham di PT Astra Internasional, Tbk periode 2009-2018?

\section{Tujuan Penelitian}

Setelah dibuat perumusan masalah dan analisa yang dijabarkan sebelumnya, pnelitian bertujuan:

1. Mengetahui pengaruh ROA terhadap harga saham pada PT Astra Internasional Tbk. perioed 2009-2018.

2. Mengetahuii pengaruh EPS terhadap harga saham pada PT.. Astra Internasional Tbk. period 2009-2018.

3. Meengetahui pengaruh PER terhadap harga saham pada PT Astra Internasional Tbk perioede 2009-2018.

4. Mengetahui pengaruh ROA, EPS \& PER secara bersama terhadap harga saham pada PT Astra Internasional Tbk perioede 2009-2018.

\section{TINJAUAN PUSTAKA}

\section{A. Manajemen Keuangan}

Fahmi (2014:1) bahwa, "Manajemen Keuangan perusahaan merupakan penggabungan dari ilmu dan seni yang membahas, mengkaji, dan menganalisis tentang bagaimana seorang manajer keuangan dengan mempergunakan seluruh sumber daya perusahaan untuk mencari dana, mengelola dana, dan membagi dana dengan tujuan mampu memberikan profit atau kemakmuran bagi para pemegang saham dan usaha berkelanjutan bagi perusahaan".

\section{B. Return On Assets (ROA)}

Kasmir (2015:198) "rasio ROA merupakan rasio yang menunjukkan hasil (return) atas jumlah aktiva yang digunakan ROA juga merupakan suatu ukuran tentang efektivitas manajemen dalam mengelola investasinya".

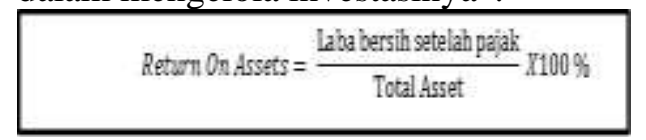

\section{Earning Per Share (EPS)}

Kasmir (2015). "Earning Per Share (EPS) adalah rasio untuk mengukur keberhasilan manajemen dalam mencapai keuntungan bagi pemegeang saham". Lalu menurut Fahmi (2012) menyatakan "Earning Per Share merupakan keuntungan yang diberikan untuk para pemegang saham dari setiap lembar saham yang dimiliki dan dapat dihitung dengan membagi laba per lembar saham dengan jumlah saham yang beredar".

$$
\text { Ecrning Per Share }=\frac{\text { laba bersih satelah pajalk }}{\text { jumlah saham yang beredar }} Z 100 \%
$$

\section{Price Earning Ratio (PER)}

PER untuk meilhat apakah pasar menghargai kinerja dari suatu perusahaan. apabila perusahaan mempunyai nilai PER yang tinggi maka peluang atau tingkat dari pertumbuhan suatu perusahaan sangat baik, sehingga investor bisa mendapatkan keuntungan yang diharapkan dari setiap laba yang didapat.

Menurut Eduardus Tandelin (2017:387) menyatakan bahwa, "Price Earning Ratio mengindikasikan banyaknya rupiah dari laba yang saat ini investor bersedia membayar sahamnya, ddengan kata lain PER merupakan harga untuk tiap rupiah laba". 
JRNAL ПММАH

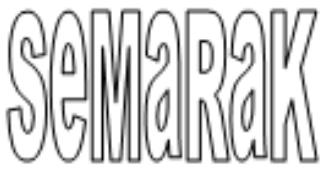

\section{E. Harga Saham}

Jogiyanto hartono (2010) menyatakan "bahwa harga saham adalah harga suatu saham yang terjadi di pasar bursa pada saat tertentu yang di tentukan oleh mekanisme pasar berupa permintaan dan penawaran saham tersebut".

Martalena \& Malinda (2011:57) menjelaskan "Harga pasar saham adalah nilai suatu saham yang di tentukan oleh permintaan dan penawaran yang terbantuk di bursa saham".

Price Earning Ratio = Harga Saham

\section{F. Hipotesis Penelitian}

Berikut dibawah ini dugaan sementara yang dapat dihasilkan dari penelitian berdasarkan paparan sebelumnya di latarbelakang, mindmap maupun kajianteori:

$\mathrm{H}_{01}$ : Diduga tidak terdapat pengaruh secara parsial antara ROA terhadap harga saham di PT Astra Internasional Tbk

$\mathrm{H}_{11}$ : Diduga terdapat pengaruh secara parsial antara ROA terhadap harga saham di PT Astra Internasional Tbk

$\mathrm{H}_{02}$ : Diduga tidak terdapat pengaruh secara parisal antara EPS terhadap harga saham pada PT Astra Internasional Tbk

$\mathrm{H}_{12}$ : Diduga terdapat pengaruh secara parisal antara EPS terhadap harga saham pada PT Astra Internasional Tbk

$\mathrm{H}_{03}$ : Diduga tidak terdapat pengaruh secara parsial antara PER terhadap harga saham pada PT Astra Internasional Tbk

$\mathrm{H}_{13}$ : Diduga terdapat pengaruh secara parsial antara PER terhadap harga saham pada PT Astra Internasional Tbk

$\mathrm{H}_{04}$ : Didiuga tidak terdapat pengaruh secara simultan antara ROA, EPS, dan PERterhadap harga saham pada PT Astra Internasional Tbk

$\mathrm{H}_{14}$ : Didiuga terdapat pengaruh secara simultan antara ROA, EPS, dan PERterhadap harga saham pada PT Astra Internasional Tbk

\section{METODE PENELITIAN}

Tempat dilakukannya penelitain adalah di PT. Astra Internasonal, Tbk yang beralamat di Jl. Jendral SudirmanKav.5-6, DKI Jakarta, Indonesia.

Penelitian ini bersifat kuantitatif, karena memerlukan uji analisis statistik untuk menguji hipotesis yang ada. Menurut Sugiyono (2013:35-36) mengatakan bahwa, "Metode kuantitaif dapat diartikan sebagai metode penelitian yang berlandaskan pada filsafat postitivisme, digunakan untuk meneliti pada populasi atau sampel tertentu, pengumpulan data menggunakan instrumen penelitian, analisis data bersifat kuantitatif/statistik, dengan tujuan untuk menguji hipotesis yang telah di tetapkan". Dalam penelitian ini, populasi yang digunakan adalah laporan keuangan dengan sampel yaitu neraca dan laporan laba rugi.

\section{HASIL DAN PEMBAHASAN}

\section{A. Gambaran Objek Penelitian}

PT Astra International Tbk berdiri tahun 1957 sebagai perusahaan perdagangan umum dengan nama Astra International Inc. Ditahun 1990, berganti nama PT Astra International Tbk, dalam penawaran umum perdana saham Perseroan kepada masyarakat, kemudian dilanjutkan dengan pencatatan saham Perseroan di Bursa Efek Indonesia dengan ticker ASII. Nilai kapitalisasi pasar Astra pada diakhir tahun 2019 adalah sebesar 280,3 triliun (rupiah).

Operasional dari bisnis ini sudah tersebar di seluruh Indonesia melalui 237 anak perusahaan selain melalui ventura bersama juga entitas asosiasi, dengan jumlah karyawan \pm 216.425 karyawan. Astra terkenal sebagai salah satu grup usaha terbesar nasional, dengan reputasi yang kuat rangkaian penawaran produk, layanan yang berkualitas dapat dilihat dari tata kelola perusahaan serta lingkungan yang baik. 
JRNAL ПММАH

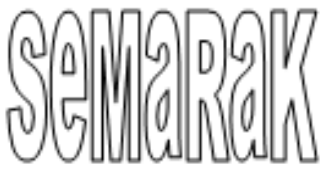

P-ISSN 2615-6849, E-ISSN 2622-3686

Jurnal Semarak,Vol.4,No.2,Juni 2021, Hal (81-89)

@Prodi Manajemen Fakultas Ekonomi Universitas Pamulang
B. Penemuan dan Pembahasan

1. Test Classic'sAssuption

a. Normality Test

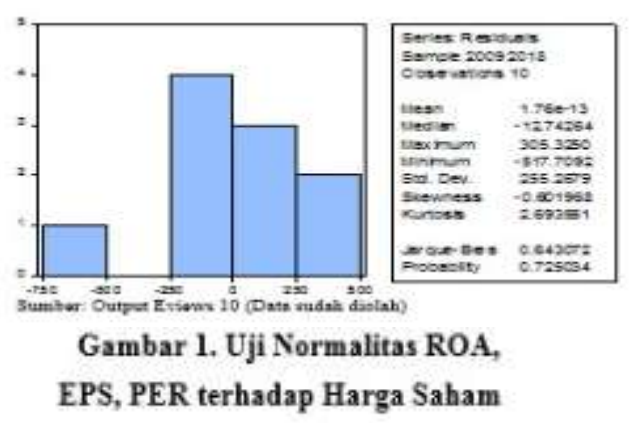

Berdasarkan gambar 1. diatas, menunjukkan bahwa penelitian untuk uji normalitas dapat dikatakan memenuhi syarat normalitas atau $\mathrm{H}_{0}$ diterima. Hal ini dapat terlihat dari nilai $J B$ adalah 0,643072 dengan probabilitas $0,725034>$ 0,05 , artinya berdistribusi normal.

\section{b. Multikolinieritas Test}

Pengujian multi kolinieritas mengunakan analisis yang dibantu program aplikasi Eviews 10 dengan ringkasan hasil uji multi sebagai berikut.

Table 1 Hasil Uji Multi kolinier

\section{Inclueted obsenzaser 10}

\begin{tabular}{|c|c|c|}
\hline \multirow[b]{2}{*}{ Veriable } & \multicolumn{2}{|c|}{ Coefficient Urcenterer Contred } \\
\hline & Veriuse IIf & VII \\
\hline C & 3216612. 329.0903 & NA \\
\hline $\mathrm{ROA}$ & $14022200 \quad 24.49994$ & 4.416839 \\
\hline $\mathbb{B S}$ & 2.07379055 .87295 & 1999075 \\
\hline$P$ PR & 3361,47990089190 & 287022 \\
\hline
\end{tabular}

Dari Tabel 1 tersebut menunjukkan nilai VIF variabel independen $\operatorname{ROA}\left(\mathrm{X}_{1}\right)$ adalah 4,416833, EPS $\left(\mathrm{X}_{2}\right)$ sebesar 1,999075, dan PER $\left(\mathrm{X}_{3}\right)$ sebesar 2,876022. Masing masing nilai VIF tiap variabel $<10$, maka tidak terjadi multikolinearitas.

\section{c. Test Heterokedastisitas}

Imam Ghozali (2018) “apabila nilai $O b s * R$-Squared melebihi tigkat signifikan $(\alpha=0,05)$ maka dapat dikatakan tidak terjadi heteroskedastisitas".

Table 2 Hasil Uji Heteroskedastisitas

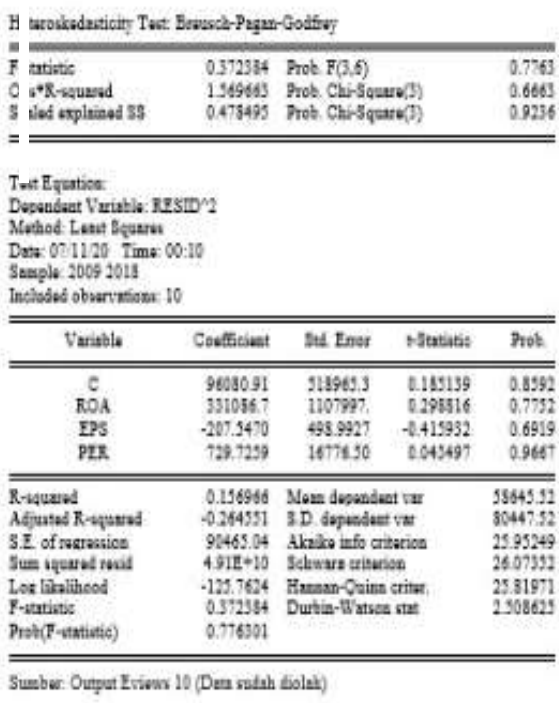

Dapat dilihat pada tabel2 menunjukkan uji Heteroskedastisitas dengan metode Breusch-Pagan-Godfrey, nilai $O b s * R$-Squared yang ditunjukan dengan nilai probabilitas-chi square sebesar $0,6663>0,05$. Hasil juga menunjukkan masing-masing variabel > dari taraf signifikan yaitu 0,05 nilai probabilitas ROA adalah 0.7752 , nilai probabilitas EPS adalah 0,6919, dan nilai probabbilitas PER adalah 0,9667. Dengan demikian model regresi tersebut menunjukan tidak terjadi gejala Heteroskedastisitas.

\section{d. Test Autokorelasi}

Tujuan dari Uji autokorelasi adalah mencari adakah hubungan antara residual satu obserfasi dengan residual observasi lainnnya pada periode sekarang dan sebelumnya.

Table 3 Hasil Uji Autokorelasi 
JRNAL ПММАH

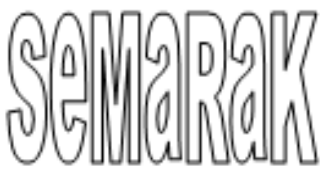

Jurnal Semarak,Vol.4,No.2,Juni 2021, Hal (81-89)

@Prodi Manajemen Fakultas Ekonomi Universitas Pamulang

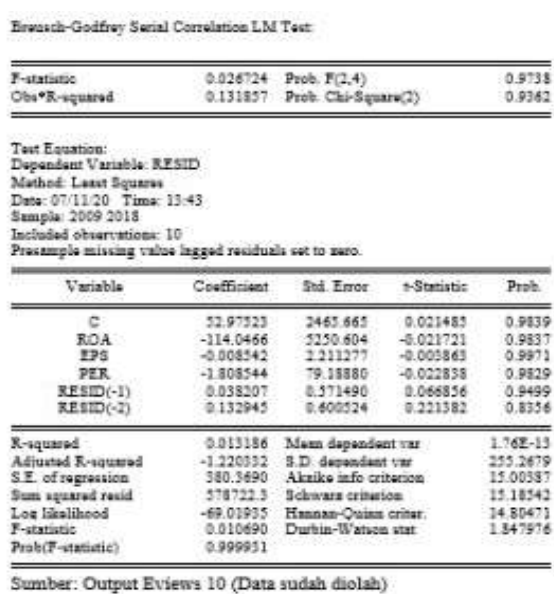

Dari tabel 3 diatas nilai $D W$ sebesar 1,847976 dimana nilai masuk pada rentang antara 1,54-2,46 yang berarti tidak terjadi autokorelasi

\section{Pengaruh Secara Partial}

\section{Table 4 Hasil Uji Partial t}

\begin{tabular}{|c|c|c|c|c|}
\hline Varlabie & Coenciant & Sil Error & bStabste & Prob. \\
\hline C & 4547.238 & 1793.492 & -2.535411 & 0.0444 \\
\hline $\mathrm{ROA}$ & 4617.416 & 3629.128 & 1.205567 & 0.2759 \\
\hline EPS & 1324079 & 1.724468 & 7.678188 & 0.0003 \\
\hline PER & 383.5624 & 57.97790 & 5.759268 & 0.0012 \\
\hline R-squared & 0.971583 & \multicolumn{2}{|c|}{ Mean dependent var } & 6870000 \\
\hline Acjoesd Raquared & 0.567357 & \multicolumn{2}{|c|}{ S. D. dependent vat } & 1514.680 \\
\hline SE of reortession & 3126390 & \multirow{2}{*}{\multicolumn{2}{|c|}{$\begin{array}{l}\text { Akake into crilerion } \\
\text { Sohvarz crtierion }\end{array}$}} & 1661714 \\
\hline Sum Equared reald & 5884652 & & & 14.73818 \\
\hline LO4 ixtilnood & .69 .05572 & \multirow{2}{*}{\multicolumn{2}{|c|}{$\begin{array}{l}\text { Mastas-Quan ortef. } \\
\text { Dutoln-Watson atat }\end{array}$}} & 16.69437 \\
\hline F-statiatc & 68.41732 & & & 1.730359 \\
\hline Pred(F-statute) & 0.000080 & & & \\
\hline
\end{tabular}

Sunber: Outpat ETims 10 (Dra sudah diolak)

Dari tabel 4 diatas, variabel ROA menunjukan nilai $t_{\text {hitung }}$ sebesar 1,205867 lebih kecil dari $(<) \mathrm{t}_{\text {tabel }} 2,44691(1,205867$ $<2,44691$ ) dan nilai probabilitas nya sebesar 0,2733. Artinya ROA tiidak berpengaruh terhadap harga saham.

Selanjutnya untuk hasil variabel $P E R$ terhadap harga saham menunjukan nilai dari $t_{\text {hitung }}$ sebesar $7,678188>t_{\text {tabel }}$ 2,44691). Artinya bahwa EPS berpengaruh signifikan terhadap harga saham hal ini diperkuat oleh nilai probabilitas $0,0003<0,05$.
Untuk (Uji t) di tabel4 antara variable PER terhadap harga saham diperoleh $t_{\text {hitung }}$ sebesar 5,753268. Sehingga $t_{\text {hitung }}$ lebih besar dari pada $t_{\text {tabel }}(5,753268>2,44691)$ dengan nilai probabilitas $0,0012<0,05$. PER memiliki pengaruh signifiikan terhadap harga saham.

\section{Pengaruh Simultanous}

Uji pengaruh secara bersama, dengan kata lain Uji $F$ mnejelaskan ada atau tidaknya signifikansi hasil analisis regresi.

Table 5 Hasil Uji Simultan F

\begin{tabular}{|c|c|c|c|c|}
\hline Varlable & Coettolest & St1. Ertor & t-statiatic & Prob \\
\hline c & -4547.238 & 1793.492 & -2535611 & 0.04 \\
\hline ROA & 4617.416 & 3829.126 & 1.205367 & 0.273 \\
\hline EPS & 1324079 & 1,724458 & 7.678138 & 0.000 \\
\hline PER & 333.5624 & 57.97790 & 5.753268 & 0.0012 \\
\hline R-qquared & $0.9715,53$ & \multicolumn{2}{|c|}{ Mean dependent var } & 6870.00 \\
\hline Aduatsd R-squared & 0.457397 & \multirow{2}{*}{\multicolumn{2}{|c|}{$\begin{array}{l}\text { S.D. depenoent var } \\
\text { Akake info triteron }\end{array}$}} & 1514680 \\
\hline S.E of fugrestion & 3126350 & & & 14.61714 \\
\hline Sum squared resid & 5864552 & \multicolumn{2}{|c|}{ Schwar crtterion } & 1473818 \\
\hline LoQ Jikelinood & -69.08572 & \multirow{2}{*}{\multicolumn{2}{|c|}{$\begin{array}{l}\text { Hantasn-Quan oiltef } \\
\text { Durtin-Watson stat }\end{array}$}} & 14.48497 \\
\hline F-stativic & 68.41732 & & & 1.730359 \\
\hline Proo(F-statistic) & 0.000050 & & & \\
\hline
\end{tabular}

Sumber: Output Enems 10 (Des natah diolak

Berdasarkan tabel 5 hasil perhitungan dengan menggunakan Software Eviews 10 telah di peroleh bahwa nilai $\mathrm{F}_{\text {hitung }}$ sebesar 68,41732. Sehingga $F_{\text {hitung }}>F_{\text {tabel }}$ $(68,41732>4,76)$, dan memiliki nilai probabilitas $0,000050<0,05$. Artinya bahwa secara simultan ROA, EPS, dan $P E R$ berpengaruh signifikan terhadap harga saham pada PT. Astra Internasional, Tbk

\section{Koefiisien Determiinasi (Adjusted $R$ - Squared (R2)}

Pengujian ini dilakukan untuk mengukur seberapa jauh kemampuan model regresi didalam menerangkan variasi-variabel dependen. Pada uji ini nilai yang mendekati 1 berarti variable independen tersebut mampu memberikan semua informasi yang dibutuhkan untuk memprediksi variabel dependen. Begitu pun sebaliknya, apabila nilai koefisien nya kecil atau jauh dari angka satu maka 
JRNAL ПММАH

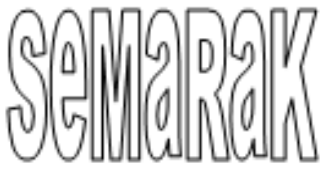

Jurnal Semarak,Vol.4,No.2,Juni 2021, Hal (81-89)

@Prodi Manajemen Fakultas Ekonomi Universitas Pamulang

kemampuan variabel independen nya dalam menjelaskan variabel dependen amat terbatas.

Berdasarkan tabel5, hasil ouput menggunakan Eviews 10 menunjukkan besarnya perolehan Adjusted R-Squared adalah 0,957397. Artinya variable independen terhadap dependen adalah $95,73 \%$ dan sisanya 4,27\% dipengaruhi oleh variable lain.

\section{KESIMPULAN\& SARAN}

\section{A. Kesimpulan}

Berıkut Point-point yang dapat peneliti simpulkan berdasar pada analisis ayng dilakukan sebeluumnya:

1. Variabel (Return On Asset)ROA tidak berpengaruh signifikan terhadap harga saham

2. EPS memiliki pengaruh yang signifikan terhadap harga saham

3. PER memiliki pengaruh yang signifikan terhadap harga saham

4. ROA, EPS, PER secara simultan berpengaruh signifikan terhadap harga saham. Pengaruh yang dimiliki sebesar 95,73\%, dan sisanya sebesar 4,27\% dipengaruhi faktor lain.

\section{B. Saran}

Peneliti memberi beberapa saran bagi perusahaan dan investor, diantaranya:

1. Perusahaan diharapkan terus meningkatkan kinerja dari perusahaan dan kinerja keuangannya untuk mendapat keuntungan yang lebih besar. Karena Return On Assets perusahaan dapat disimpulkan menunjukkan adanya trend linear menurun. Semakin tinggi rasio ini maka dapat dikatakan dapat menarik para investor untuk melakukan investasi sebesar-besarnya karena mengharapkan sebuah Return dari total asset

2. Perusahaan diharapkan terus meningkatkan nilai Earning Per Share. Karena nilai Earning Per Share yang tinggi akan menjadi salah satu faktor penentu investor dalam melakukan investasi, karena apabila nilai EPS yang tinggi menunjukkan profuktivitas perusahaan pada laba tahun berjalannya atau laba setelah pajak.

3. Perusahaan diharapkan terus meningkatkan nilai Price Earning Ratio nya, karena apabila nilai PER semakin tinggi maka investor semakin tertatik untuk menanmkan modalnya untuk berinvestasi. Karena nilai PER merupakan harga dari tiap laba yang investor dapatkan dari hasil investasinya.

4. Bagi investor sebaiknya sebelum berinvetasi, agar lebih selekif menentukan perusahaan mana yang lebih baik untuk di investasikan, dan disarankan untuk menganalisa faktorfaktor fundamental perusahaan nya terlebih dahulu sebelum menanamkan modalnya pada perusahaan.

\section{DAFTAR PUSTAKA}

Akdon dan Ridwan. 2013. Rumus dan Data dalam Analisis Statistika. Badung: Alfabeta

Brigham, Eugene F dan J.F Houston. 2010. Dasar-Dasar Manajemen Keuangan Edisi 11. Jakarta: Salemba Empat

Darmadji, Tjiptono, Fakhruddin, Hendy M. 2011. Pasar Modal Di Indonesia

Dimas, S (2019). Pengaruh Return On Assets, Earning Per Share, dan Book Value Per Share, Jurnal Samudra Ekonomi dan Bisnis, 10(2), 124-132

Eduardus, Tandelin. 2017. Portofolio dan Investasi: Teori dan Aplikasi Edisi 1. Yogyakarta: Kanisius

Fahmi, Irham, 2014. Manajemen Keuangan Perusahaan dan Pasar Modal

Fahmi, Irham. 2012, Manajemen Investasi: Teori dan Aplikasi. Jakarta: Salemba Empat 
JRNAL ПMПAH

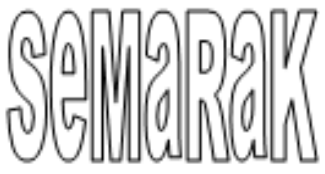

P-ISSN 2615-6849, E-ISSN 2622-3686

Jurnal Semarak,Vol.4,No.2,Juni 2021, Hal (81-89)

@Prodi Manajemen Fakultas Ekonomi Universitas Pamulang
Fahmi, Irham. 2013. Manajemen Kinerja :Teori dan Aplikasi. Bandung: Alfabeta

Ghozali, Imam, (2018). Analisis Multivariat dan Ekonometrika Teori, Konsep, dam Aplikasi dengan Eviews 10 Edisi Kedua. Semarang: Universitas Diponegoro

Hadijah Febriana. 2018 "Pengaruh Penyaluran Kredit, CAR (Capital Adequacy Ratio), NPL (Non Performing Loan) Terhadap Pendapatan Bunga dan Dampaknya Terhadap Profitabilitas (Studi Kasus pada BANK Pembangunan Daerah yang Terdaftar di BEI)" Jurnal Sekuritas (Saham, Ekonomi, Keuangan, dan Investasi) Vol.2, No. 1.

Hanafi. Mamduh M. 2014. Analisis Laporan Keuangan. Edisi 4. Yogyakarta: UUP STIM YKPN

Harahap, Sofyan Syafri. 2012. Teori Akuntansi. Edisi Revisi. Jakarta: Rajawali Pers

Harahap, Sofyan Syafri. 2015. Analisis Kritis atas Laporan Keuangan. Edisi 1-10. Jakarta: Rajawali Pers

Hasibuan, Malayu S.P. 2012. Manajemen Sumber Daya Manusia. Jakarta: PT. Bumi Aksara

Hery, Tri Admojo. 2015. Analisis Rasio Keuangan:Pendekatan Rasio Keuangan

Irnawati, J (2019). Pengaruh Return On Assets (ROA), Return On Equity (ROE), dan Current Ratio (CR) Terhadap Nilai Perusahaan dan Dampaknya Terhadap Kebijakan Deviden, Jurnal Sekuritas Unpam, 2(2), 1-13

Jogiyanto, Hartono. 2010. Teori Portofolio dan Analisis Investasi. Yogyakarta: BPFE Yogyakarta
Kasmir. 2012. Analisis Laporan Keuangan. Jakarta: PT. Raja Grafindo Persada

Kasmir. 2014. Analisis Laporan Keuangan. Cetakan Ketujuh. Jakarta: PT. Rajagrafindo Persada

Kasmir. 2015. Analisis Laporan Keuangan. Edisi Satu. Jakarta: PT. Raja Grafindo Persada

Kasmir. 2016. Analisis Laporan Keuangan. Jakarta: PT. RajaGrafindo Persada

Martalena, dan Malinda. 2011. Pengantar Pasar Modal. Edisi Pertama. Yogyakarta: Andi.

Martono, D. Agus Harjito. 2010. Manajemen Keuangan

Munawir, S. 2010. Analisis Laporan Keuangan. Edisi Keempat. Cetakan Kelimabelas. Yogyakarta: Liberty

Munawir, S.2016. Analisis Laporan Keuangan. Yogyakarta: Liberty

Oktavian, R. (2019). Pengaruh Earning Per Share (EPS), dan Dividen Per Share (DPS) Terhadap Harga Saham PT. Wijaya Karya (Persero) Tbk, Jurnal Sekuritas Unpam , 2(2), 156-171

Purnomo, S., \& Pasaribu, V. L. D. (2019). Pergerakan Harga Saham Pt Adaro Energy Tbk (Adro) Pada Pengumuman Dividen Interim Tahun Buku 2018. Jurnal Ekonomi Efektif, 2(1).

Santy, Ariesta D.V (2017). Pengaruh ROA, ROE, dan EPS Terhadap Harga saham PT. Garuda Indonesia, Tbk, Jurnal Ilmu dan Riset Manajemen, 6(9)

Sartono, Agus . 2015. Manajemen Keuangan Teori dan Aplikasi. Edisi keempat. Yogyakarta:BPFE.

Sugiyono. 2013. Metode Penelitian Manajemen. Cetakan Kesatu. Bandung: Alfabeta 
JRNAL ПMПAH

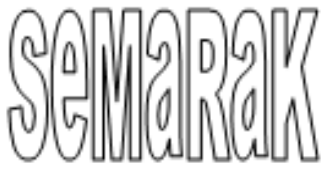

P-ISSN 2615-6849, E-ISSN 2622-3686

Jurnal Semarak,Vol.4,No.2,Juni 2021, Hal (81-89)

@Prodi Manajemen Fakultas Ekonomi Universitas Pamulang
SUTIMAN, S. (2020). PENGARUH SET PELUANG INVESTASI, RASIO PEMBAYARAN DIVIDEN DAN BEBAN KEUANGAN TERHADAP PRICE BOOK VALUE PADA PERUSAHAAN MANUFAKTUR YANG TERDAFTAR DI BURSA EFEK INDONESIA PERIODE 20122016

Sutrisno. 2012. Manajemen Keuangan Teori, Konsep, dan Aplikasi. Edisi Kedelapan. Yogyakarta: GrahaIlmu

Timan, S. (2017). ANALISIS SUMBER DAN PENGGUNAAN DANA DALAM UPAYA PENINGKATAN LIKUIDITAS DAN KEMAMPULABAAN PADA PT BANK X (PERSERO). Jurnal Mandiri: Ilmu Pengetahuan, Seni, dan Teknologi, 1(2), 289-310.

Timan, S. (2019). ANALISIS RASIO ROA DAN ROE DALAM MENILAI TINGKAT KESEHATAN PADA PT BANK MANDIRI (PERSERO) TBK TAHUN 2012-2017. Jurnal Mandiri: Ilmu Pengetahuan, Seni, dan Teknologi, 3(1), 20-36.

Viandita, T.O., Suhadak, dan Husaini A. (2013). Pengaruh Debt Ratio (DR), Price Earning Ratio (PER), Earning Per Share (EPS), dan Size Terhadap Harga Saham, Jurnal Administrasi Bisnis, 1(2), 113-121

Wartono, T., Tumanggor, M., Oktrima, B., \& Delimah, V. L. (2021, January). Analysis of Ratio and Financial Performance of Open Company Pharmaceutical Industry Which has Been Listing in Indonesia Stock Exchange (Case Study in Pharmaceutical Company PT. Kimia Farma. Tbk). In INCEESS 2020: Proceedings of the 1st International Conference on Economics Engineering and Social Science, InCEESS 2020, 17-18 July, Bekasi,
Indonesia (p. 268). European Alliance for Innovation.

Widoatmodjo, Sawidji. 2012. Cara Sehat Investasi di Pasar Modal. Edisi Revisi. Jakarta: PT. Jurnalindo Aksara Grafika Yogyakarta: CAPS 